\title{
FUNGSI BADAN USAHA MILIK DESA (BUMDes) DALAM UPAYA MENINGKATKAN KONDISI KEHIDUPAN SOSIAL EKONOMI MASYARAKAT (Studi di Desa Bahomotefe Kecamatan Bungku Timur Kabupaten Morowali)
}

\author{
Akfan $^{1}$, Juhaepa ${ }^{2}$, Suharty Roslan ${ }^{3}$ \\ ${ }^{123}$ Jurusan Sosiologi FISIP Universitas Halu Oleo, Kendari, Indonesia \\ 1Email korespondensi: akfandi98@gmail.com
}

\begin{abstract}
ABSTRAK
Tujuan penelitian ini adalah untuk mengetahui Fungsi BUMDes Citra Abadi dalam upaya meningkatan kondisi kehidupan sosial ekonomi masyarakat di Desa Bahomotefe Kecamatan Bungku Timur Kabupaten Morowali. Metode penelitian ini yaitu menggunakan metode deskriptif kualitatif dengan teknik pengumpulan datanya yaitu, observasi, wawancara, dokumentasi. Hasil penelitian di lapangan menunjukan bahwa fungsi badan usaha milik desa (BUMDes) dalam upaya meningkatkan kondisi kehidupan sosial ekonomi masyarakat di Desa Bahomotefe Kecamatan Bungku Timur Kabupaten Morowali yaitu fungsi BUMDes dalam upaya meningkatan kondisi kehidupan masyarakat, BUMDes yang berada di desa Bahomotefe masih belum secara signifikan menjalankan fungsinya dalam upaya meningkatkan kondisi sosial. Namun fungsi BUMDes bagi pengembangan perekonomian masyarakat sudah bisa dikatakan memberi peningkatan. Adapun indikator Fungsi BUMDes dalam Upaya Meningkatan Kondisi kehidupan sosial ekonomi Masyarakat berupa: meningkatkan peranan masyarakat desa yaitu fungsi BUMDes dalam meningkatkan peranan masyarakat desa sudah memberikan pengaruh pada upaya peningkatan kondisi sosial yaitu pada interaksi sosial Sedangkan pada kondisi sosial pendidikan dan kesehatan belum memberikan fungsi yang khusus, menumbuhkembangkan kegitan ekonomi masyarakat yaitu fungsi BUMDes dalam menumbuhkembangkan kegiatan ekonomi masyarakat desa sudah memberikan pengaruh pada upaya peningkatan kondisi ekonomi yaitu pada pemenuhan kebutuhan rumah tangga melalui Unit Usaha pasar Kampung/Desa dan meningkatkan pendapatan masyarakat serta pendapatan asli desa (PADes) yaitu fungsi BUMDes dalam meningkatkan sumber pendapatan masyarakat dan pendapatan Asli Desa (PADes) sudah memberikan pengaruh pada upaya peningkatan kondisi ekonomi yaitu pada pendapatan melalui Unit Usaha pasar Kampung/Desa dan Unit Usaha Peternakan yang di jalankan oleh BUMDes.
\end{abstract}

Kata Kunci: Fungsi BUMDes, Kehidupan Sosial Ekonomi Masyarakat. 


\section{ABSTRACT}

The purpose of this study was to determine the function of BUMDes Citra Abadi in an effort to improve the socio-economic conditions of the community in Bahomotefe Village, Bungku Timur District, Morowali Regency. This research method is using descriptive qualitative method with data collection techniques, namely, observation, interviews, documentation. The results of research in the field show that the function of village-owned enterprises (BUMDes) in an effort to improve the socio-economic conditions of the community in Bahomotefe Village, Bungku Timur District, Morowali Regency, namely the function of BUMDes in an effort to improve the living conditions of the community, BUMDes in Bahomotefe Village are still not significant carry out its function in an effort to improve social conditions. However, the function of BUMDes for the development of the community's economy can be said to provide an increase. The BUMDes function indicators in an effort to improve the socio-economic conditions of society in the form of: increasing the role of the village community, namely the function of the BUMDes in increasing the role of the village community, which has had an influence on efforts to improve social conditions, namely on social interaction. Developing community economic activities, namely the function of BUMDes in developing economic activities of rural communities, has had an influence on efforts to improve economic conditions, namely meeting household needs through the Village I Village market Business Unit and increasing community income and village original income (PADes), namely the function of BUMDes in increasing the source of community income and Village Original income (PADes) has had an influence on efforts to improve economic conditions, namely on income through the Village / Village market Business Unit and the Animal Husbandry Business Unit which are netted. nkan by BUMDes.

Keywords: BUMDes Function, Community Socio-Economic Life.

\section{PENDAHULUAN}

Badan Usaha Milik Desa (BUMDes) adalah lembaga usaha desa yang dikelola oleh masyarakat dan pemerintahan desa dalam upaya memperkuat perekonomian desa dan dibentuk berdasarkan potensi desa. BUMDes sebagai suatu lembaga ekonomi modal usaha menganut asas mandiri. Badan usaha ini sesungguhnya telah diamanatkan didalam UU No. 32 Tahun 2004 tentang Pemerintahan Daerah dan Peraturan Pemerintah No. 71 Tahun 2005 tentang Desa. Pendirian badan usaha ini harus disertai dengan upaya penguatan kapasitas dan didukung oleh kebijakan daerah (Kabupaten/Kota) yang memfasilitasi dan melindungi usaha ini dari ancaman persaingan para pemodal besar. BUMDes merupakan lembaga ekonomi yang baru beroperasi di pedesaan dan masih membutuhkan landasan yang kuat untuk tumbuh dan berkembang. Dimana pembangunan landasan bagi pendirian BUMDes adalah pemerintah.

Pendirian BUMDes didasarkan pada kebutuhan dan potensi desa, sebagai upaya peningkatan kesejahteraan masyarakat (Harita dkk., 2020). Berkenaan 
dengan perencanaan dan pendiriannya, BUMDes dibangun atas prakarsa (inisiasi) masyarakat. BUMDes merupakan pilar kegiatan ekonomi di desa yang berfungsi sebagai lembaga sosial dan komersial. BUMDes sebagai lembaga sosial berpihak pada kepentingan masyarakat melalui kontribusinya dalam penyediaan pelayanan sosial. Sedangkan sebagai lembaga komersial bertujuan mencari keuntungan melalui penawaran.

Sumber daya lokal (barangdan jasa) ke pasar. BUMDes dibentuk berdasarkan pada perundang-undangan yang berlaku dan sesuai dengan kesepakatan yang terbangun di masyarakat desa. Dengan demikian Badan Usaha Milik Desa (BUMDes) dapat beragam pada setiap desa yang ada karena sesuai dengan karakteristik lokal, potensi, dan sumber daya yang dimiliki masing-masing desa.

Pendirian BUMDes juga didasari oleh UU No. 6 tahun 2014 tentang Desa dalam Pasal 87 ayat (1) yang berbunyi, "Desa dapat mendirikan Badan Usaha Milik Desa yang disebut BUMDes," dan ayat (2) yang berbunyi, "BUMDesa dikelola dengan semangat kekeluargaan dan kegotongroyongan," dan ayat (3) yang berbunyi, "BUMDesa dapat menjalankan usaha di bidang ekonomi dan atau pelayanan umum sesuai dengan ketentuan peraturan perundangundangan. Dengan adanya Badan Usaha Milik Desa (BUMdes) pemerintah desa memiliki hak pengolaan sumber daya alam dan sumber daya manusia secara mandiri, sehingga pemerinta desa bisa menentukkan program yang sesuai dengan potensi desa tersebut.

Desa Bahomotefe merupakan salah satu desa dataran rendah di Kecamatan Bungku Timur Kabupaten Morowali. Desa ini memiliki potensi yang dapat di optimalkan untuk meningkatkan kualitas perekonomian masyarakatnya, diantaranya potensi pengelolaan pendapatan pasar yang berkembang, aset-aset desa yang ada, dan merupakan desa lingkar tambang atau bisa dikatakan desa yang dikelilingi banyak perusahaan pertambangan. Sehingga BUMDes sebagai sarana untuk membantu perekonomian masyarakat merupakan yang menarik dan tidak asing lagi dikalangan peneliti.

Pada penelitian yang dilakukan oleh Ni Luh Putu Sri Purnama Pradnyani (2019) yang berjudul "Peran Badan Usaha Milik Desa (BUMdes) Dalam Meningkatkan Kesejahteraan Masyarakat Di Desa Tibubeneng Kuta Utara". Hasil penelitian menunjukkan peranan BUMdes Gentha Persada dalam 
mensejahterakan masyarakat telah diwujudkan dengan adanya unit-unit usaha yang ada didalamnya seperti unit usaha simpan pinjam, jasa sampah, money charger, dan perdagangan. BUMdes juga membuka lapangan pekerjaan bagi masyarakat desa Tibubeneng sehingga mengurangi pengangguran. Selain itu BUMdes Gentha Persada sudah memberikan pembagian keuntungan untuk menambah pendapatan asli desa Tibubeneng.

Pada penelitian yang dilakukan Ade Eka Kurniawan (2015) yang berjudul “Peranan Badan Usaha Milik Desa (BUMdes) Dalam Meningkatkan Pendapatan Asli Desa Di Desa Lanjut Kecamatan Singkep Pesisir Kabupaten Lingga". Hasil penelitian, berdasarkan hasil penelitian peranan badan usaha milik desa (BUMdes) dalam peningkatan pendapatan asli desa sudah dikatakan meningkat, walaupun dari tahun ke tahun ada mengalami peningkatan dan penurunan. Maka peranan BUMdes dapat dilihat dari beberapa indikator yang menjadi alat ukur dari sebuah penelitian ini:

1. Peranan BUMDes sebagai fasilitator dalam meningkatkan pendapatan asli desa sudah bisa dikatakan baik dan aktif

2. Peranan BUMDes sebagai mediator dalam meningkatkan pendapatan asli desa berjalan dengan mestinya hal ini dapat dilihat dari BUMDes mendukung penuh pengembangan kegiatan usaha desa yang dilaksanakan di Desa Lanjut.

3. Peranan BUMDes sebagai motivator dalam meningkatkan pendapatan asli desa sudah baik.

4. Peranan BUMDes sebagai dinamisator dalam peningkatan pendapatan asli desa tidak berjalan dengan baik, dikarenakan ketua BUMDes mengatakan sendiri bahwa jika badan usaha itu telah berjalan maka masyarakat yang berhak menanggapi bagaimana baik dan tidaknya sebab masyarakat langsung yang memanfaatkan hasil dari usaha desa tersebut.

Secara subtantif, penelitian terdahulu perihal tema BUMDes dalam konteks nasional terpola pada dua kajian utama. Pertama, sebagian penelitian menguraikan tentang meningkatkan kesejahteraan masyarakat. Kedua, umumnya penelitian terdahulu cenderung menyajikan tentang peningkatan pendapatan asli desa. Lain halnya dengan penelitian ini yang akan terfokus pada fungsi BUMDes dalam upaya meningkatkan kondisi kehidupan sosial ekonomi masyarakat dalam artian bahwa kehidupan masyarakat ini akan 
mengalami peningkatan dengan adanya fungsi BUMDes dalam mengembangan bidang usaha.

Kebaruan ontologis sebagai state of the art penelitian kemudian diperkuat oleh fakta sosiologis yang menunjukan bahwa Pada Tahun 2018 pemerintah Desa Bahomotefe membentuk Badan Usaha Milik Desa (BUMDes) CITRA ABADI yang di dalamnya terdapat fungsi pengelolaan pada bidang usaha seperti bidang usaha pengeloaan hasil pendapatan pasar desa. Bentuk pengelolaan yang sudah dilakukan seperti menata tempat jualan, memberikan pungutan karcis bagi pedagang pasar, pungutan biaya parkir kendaraan, renovasi bangunan permanen pasar, juga perluasan pasar. Akan tetapi sejak adanya pasar yang dikelolah oleh BUMDes tersebut belum secara signifikan merubah perekonomian kehidupan pedagang. Paparan fenomena empiris di atas menunjukkan bahwa fungsi BUMDes dalam upaya meningkatkan kondisi kehidupan sosial ekonomi masyarakat di tengah-tengah arus modern masih membutuhkan perhatian yang lebih dalam menjalankan fungsinya.

\section{METODE PENELITIAN}

Jenis metode penelitian ini adalah penelitian dengan metode deskriptif kualitatif. Penelitian deskriptif kualitatif yaitu metode penelitian yang digunakan untuk meneliti obyek yang alamiah. Pada penelitian kualitatif, peneliti menyajikan hasil penelitian secara deskriptif yaitu mendeskripsikan data yang dikumpulkan berupa kata-kata, gambar, dan bukan angka. informan dalam penelitian ini yaitu berjumlah 7 orang, semua informan merupakan masyarakat Desa Bahomotefe Kecamatan Bungku Timur Kabupaten Morowali yang terdiri dari kepala desa, bendahara BUMDes, ketua BUMDes beserta anggotanya dan masyarakat desa.

Jenis data yang di gunakan yaitu data kuantitatif dan data kualitatif. Data kuantitatif yaitu data informasi yang berupa angka-angka atau bilangan. Data ini dibutuhkan untuk menunjukkan jumlah masyarakat di Desa Bahomotefe Kecamatan Bungku Timur Kabupaten Morowali. Kemudian data kualitatif yaitu data informasi yang berbentuk penjelasan dan uraian yang di deskripsikan. Data diperoleh melalui suatu proses menggunakan teknik analisis secara langsung yakni dengan melakukan wawancara atau observasi 
pada masyarakat di Desa Bahomotefe Kecamatan Bungku Timur Kabupaten Morowali. Data akan di peroleh melalui sebuah proses yaitu dengan menggunakan teknik analisis, yaitu dengan cara melakukan observasi, wawancara dan dokumentasi. Observasi atau pengamatan yaitu pengumpulan data aktivitas terhadap suatu proses atau objek dengan maksud merasakan dan kemudian memahami sebuah fenomena untuk mengetahui informasi-informasi yang di butuhkan. Wawancara yaitu pengumpulan data dengan cara melakukan wawancara terhadap objek penelitian di Desa Bahomotefe Kecamatan Bungku Timur Kabupaten Morowali. Dan dokumentasi yaitu mengambil data-data dari dokumen serta literatur yang ada kaitannya dengan penelitian ini.

Analisis data dalam penelitian ini menggunakan metode analisis deskriptif (Asaka \& Awarun, 2020). Metode analisis deskriptif merupakan metode penelitian dengan cara mengumpulkan data-data sesuai dengan yang sebenarnya kemudian data tersebut disusun, diolah, dan dianalisis untuk memberikan gambaran mengenai masalah yang ada. Proses deskripsi data pada dasarnya meliputi upaya penelusuran dan pengungkapan informasi yang relevan yang terkandung dalam data dan penyajian hasilnya dalam bentuk yang lebih ringkas dan sederhana, sehingga pada akhirnya mengarah pada keperluan adanya penjelasan dan penafsiran.

Data-data yang diperoleh dalam penelitian ini dianalisis secara kualitatif dengan mendeskripsikan data-data yang telah dikumpulkan. Penelitian yang dilakukan dengan menggunakan tipe kualitatif, dilakukan dengan pengamatan peserta yang menjadi subyek penelitian. Hasil pengamatan ini dituangkan dalam sebuah catatan lapangan sebagai salah satu sumber data. Setiap informasi yang telah dikumpulkan dalam catatan lapangan baik data utama dari hasil wawancara ataupun data penunjang lainnya dilakukan analisa data, yang pada akhirnya dapat menghasilkan suatu analisa data yang baik yang dapat mengungkapkan permasalahan dari penelitian ini (Sugiyono, 2018). 


\section{PEMBAHASAN}

\section{Fungsi Badan Usaha Milik Desa (BUMDes) Dalam Upaya Meningkatkan Kondisi Kehidupan Sosial Ekonomi Masyarakat}

\section{Meningkatkan Peranan Masyarakat Desa}

Dengan adanya BUMDes di Desa Bahomotefe sebagai suatu badan usaha seperti pada penjelasan permendes yang berbunyi " Menurut Peraturan Mentri Desa, Pembangunan Daerah Tertinggal, Dan Trasmigrasi RI No.4 Tahun 2015 Tentang Pendirian, Pengurusan, Pengelolaan, Dan Pembubaran Badan Usaha Milik Desa". Tentu dalam pembentukan dan pelaksanaannya tidak hanya melibatkan pemerintah desa dan pengurus BUMDes saja melainkan juga peran dari masyarakat itu sendiri. Dimana mulai dari awal pembentukkan BUMDes Bahomotefe itu sendiri masyarakat sudah ikut berperan aktif didalamnya, sampai pada proses pelaksanaanya pun masyarakat itu berperan sebagai pelaku usaha/ pendukung usaha.

Dari pengamatan dilapangan fungsi BUMDes Citra Abadi dalam Meningkatkan Peranan Masyarakat Desa sudah memberi pengaruh dikalangan masyarakat dalam hal pada kondisi sosial yaitu interaksi sosial. Fungsi BUMDes dalam Meningkatkan Peranan Masyarakat Desa berpengaruh pada upaya peningkatan kondisi sosial yaitu pada interaksi sosial yang mana dapat dilihat dalam proses pembentukan sampai pada tingkat pelaksanaan BUMDes Bahomotefe sudah terbangun interaksi sosial seperti hubungan yang menyangkut perseorangan, menyangkut antara kelompok-kelompok. Keberadaan BUMDes ini juga diketahui masyarakat melalui interaksi sosial. Namun dengan adanya BUMDes di Bahomotefe, Belum secara signifikan memberdayakan masyarakat secara keseluruhan walaupun sebagian lainnya sudah merasakan fungsi dari keberadaan BUMDes ini.

Sedangkan pada Pendidikan masyarakat Desa Bahomotefe menerapkan tingkat pendidikan minimal 9 tahun atau setara dengan tingkat pendidikan SMP/SLTP, serta sebagian yang lainnya hanya sampai ditingkat berpendidikan SD. Selain itu jika dilihat dari data yang terkait di Desa Bahomotefe tidak sedikit yang melanjutkan ke jenjang pendidikan yang lebih tinggi seperti diploma S1/S2. Tetapi ada pula yang belum termaksud usia sekolah. Dari data jumlah penduduk berdasarkan tingkat pendidikan bisa dilihat tingkat 
pendidikan Desa Bahomotefe sudah tergolong baik. Jumlah penduduk terbesar berdasarkan tingkat pendidikan yaitu tamat SMA/ sederajat dengan jumlah 559 orang. Dengan tingkat kesadaran akan pendidikan sudah meningkat seiring berjalannya era perkotaan. Dibuktikan adanya diploma IV dan atau Strata I dengan jumlah 92 orang. Meningkatnya kesadaran masyarakat dalam tingkat pendidikan merupakan salah satu faktor menentukan keberhasilan perekonomian masyarakat. Peran pendidikan sangat penting dikalangan masyarakat khususnya masyarakat pedesaan, karena pendidikan merupakan salah satu indikator dalam kesejahteraan masyarakat dimana semakin tinggi pendidikan yang ditempuh maka dapat meningkatkan pendapatan serta dapat memberdayakan masyarakat disekitarnya dengan ilmu yang dimiliki.

Dalam hal ini BUMDes Citra Abadi belum banyak mendorong pendidikan tinggi bagi masyarakat Desa Bahomotefe, karena operasional lembaga perekonomian yang telah lahir 3 tahun lalu ini masih sangat kurang bahkan dapat dikatakan kontribusinya hanya beberapa persen saja bagi kalangan masyarakat Desa Bahomotefe. Unit-init usaha yang dikelolah BUMDes Citra Abadi belum dapat menjadi tumpuan dalam meningkatkan kesejahteraan rumah tangga masyarakat Bahomotefe untuk melanjutkan pendidikan kejenjang perguruan tinggi. Maka dari itu, tingkat pendidikan khusunya anakanak mereka hanya sampai pada tingkat Sekolah Menengah Atas (SMA/sederajat), sedangkan yang masuk perguruan tinggi diploma ataupun srata hanya beberapa orang saja.

Kemudian pada kesehatan, kesehatan masyarakat Bahomotefe secara umum cukup baik. Sudah ada posyandu yang tersedia, pusat kesehatan masyarakat (PUSKESMAS). Disamping tingkat kesehatan masyarakat Desa Bahomotefe cukup baik dengan tidak adanya anak yang kekurangan gizi atau gizi buruk). Kesehatan masyarakat Bahomotefe secara umum cukup baik, tidak ada angka gizi buruk. Sudah ada posyandu yang tersedia, pusat kesehatan masyarakat (PUSKESMAS). Masyarakat Desa Bahomotefe juga menerapkan menerapkan hidup sehat dan patuh dalam membuang sampah pada tempatnya serta menjaga kesehatan lingkungan dengan teratur membersihkan rumah. Kebutuhan obat-obatan juga tersedia di warung atau pusat kesehatan yang seperti puskesmas kecuali bila memiliki penyakit yang serius dan harus ditangani oleh dokter maka obatnya harus menggunakan resep dokter. 
Kebersihan dan kesehatan masyarakat terjaga dengan baik sehingga tidak menimbulkan penyakit yang berbahaya.

Dalam hal kesehatan BUMDes Citra Abadi tidak memiliki fungsi khusus ataupun adanya unit usaha yang langsung menjurus pada pada bidang kesehatan, melihat tingkat kesehatan masyarakat Bahomotefe sendiri sudah cukup baik. Disini juga BUMDes belum memberikan fungsi untuk peningkatan kesahatan bagi masyarakatn di Desa Bahomotefe karna yang terlihat bahwa BUMDes ini lebih terfokus pada peningkatan ekonomi.

\section{Menumbuhkembangkan Kegiatan Ekonomi Masyarakat Desa}

BUMDes Bahomotefe memiliki fungsi yang penting dalam menumbuhkembangkan kegiatan ekonomi masyarakat. Dengan keberadaan BUMDes ini dalam menjalankan Program-programnya sekarang ini, tentu BUMDes ini berperan aktif dalam menumbuhkembangkan kegiatan ekonomi masyarakat. Yang mana dapat dilihat adanya peningkatan pelaku usaha dan juga kegiatan usaha yang dijalankan seperti Unit Usaha Pasar Kampung/Desa dan Unit usaha Peternakan. Dari pengamatan dilapangan fungsi BUMDes Citra Abadi dalam Menumbuhkembangan Kegiatan Ekonomi Masyarakat Desa sudah memberi pengaruh dikalangan masyarakat dalam hal pada pemenuhan kebutuhan keluarga. Dalam hal memenuhi kebutuhan hidup seperti kebutuhan pokok sandang, papan, pangan dapat dikatakan cukup. Dimana pola konsumsi rumah tangga merupakan salah satu indikator kesejahteraan rumah tangga/keluarga. Pemenuhan kebutuhan masyarakat dikelompokkan menjadi dua kelompo yaitu pemenuhan pangan dan barang-barang bukan pangan. Poroporsi pemenuhan pangan dan bukan pangan juga digunakkan sebagai indikator untuk menentukkan tingkat kesejahteraan atau ketahan pangan rumah tangga. Masyarakat Desa Bahomotefe dalam memenuhi kebutuhan konsumsinya tidak selalu sama. Bagi masyarakat yang berpenghasilan rendah tentu mereka memiliki tingkat pola konsumsi yang terbatas dikarenakan pendapatannya harus di bagi-bagi dengan pemenuhan untuk pangan dan bukan pangan, sedangkan untuk yang berpenghasilan sedang tidak semua masyarakat memiliki tingkat pola konsumsi tinggi ada pula yang pola konsumsinya rendah. Sedangkan pemenuhan untuk pendidikan dan kesehatan 
juga disesuaikan dengan kemampuan pendapatan masing-masing masyarakat. Dengan adanya Unit Usaha pasar Kampung/Desa bisa membantu masyarakat khususnya masyarakat yang berpenghasilan rendah dalam berjualan dan berbelanja untuk pemenuhan kebutuhan ruman tangga.

Fungsi BUMDes dalam Menumbuhkembangan Kegiatan Ekonomi Masyarakat Desa dapat membantu dalam pemenuhan kebutuhan rumah tangga melalui Unit Usaha pasar Kampung/Desa. Disini BUMDes Citra Abadi dalam Unit Usaha pasar desa membantu masyarakat, dimana masyarakat dapat memenuhi kebutuhan sehari-hari mereka dengan berjualan dan berbelanja dipasar desa yang telah ada dengan harga yang relatif terjangkau sehingga tidak perlu jauh jauh harus kepasar yang berada di Kecamatan/Kota untuk memenuhi kebutuhan sehari-harinya. Walaupun unit usaha pasar desa dapat membantu masyarakat dalam memperoleh kebutuhan sehari-hari dengan lebih muda dan lebih dekat, tetapi tidak mempengaruhi komposisi pemenuhan pangan masyarakat. Pemenuhan untuk pendidikan dan kesehatan pada masing-masing masyarakat tidak dapat ditentukan dalam hitungan rupiah.

\section{Meningkatkan Pendapatan Masyarakat serta Pendapatan Asli Desa (PADes)}

Anggaran Pendapatan dan Belanja (APB) Desa merupakan modal atau dana yang dijadikan aset dalam pengembangan kegiatan usaha dan dalam menjalankan program-program BUMDes, dimana program-program BUMDes Citra Abadi yang masih aktif itu adalah Unit Usaha pasar Kampung/Desa dan Unit Usaha Peternakan. Secara tidak langsung tentu BUMDes Citra Abadi berperan dalam peningkatan sumber pendapatan masyarakat dan pendapatan asli desa (PADes).

Dari pengamatan dilapangan dengan adanya anggaran pendapatan dan belanja(APB) Desa yang menjadi modal dalam pengembangan kegiatan usaha seperti Unit Usaha pasar Kampung/Desa dan Unit Usaha Peternakan tentu fungsi BUMDes dalam meningkatkatkan pendapatan masyarakat dan pendapatan asli Desa (PADes) berpengaruh pada pendapatan masyarakat yang berpenghasil rendah. Pendapatan masyarakat dalam memenuhi kebutuhan 
hidup seperti kebutuhan pokok sandang, papan, pangan, pendidikan dan kesehatan sudah dapat dikatakan cukup. Pendapatan masyarakat Desa Bahomotefe ini sudah dapat mencukupi kebutuhan sehari-hari keluarganya.

Fungsi BUMDes dalam Meningkatkan Pendapatan Masyarakat dan Pendapatan Asli Desa (PADes) Desa dapat membantu meningkatkan pendapatan masyarakat melalui Unit Usaha yang dijalankan oleh BUMDes yaitu Unit Usaha pasar Kampung/Desa dan Unit Usaha Peternakan. Dari unitunit usaha yang dikelolah BUMDes belum banyak membantu peningkatan pendapatan masyarakat berpenghasilan renda dimana sudah beroperasi selama 3 tahun terakhir. Seharusnya BUMDes Citra Abadi perlu memaksimalkan lagi unit-unit usaha yang dimiliki sehingga dapat membantu masyarakat dalam meningkatkan pendapatannya melalui usaha-usaha yang dikelolah oleh BUMDes Citra Abadi. Sehingga masyarakat tidak hanya bisa memenuhi kebutuhan sehari-harinya saja tetapi juga dapat menyisihkan pendapatannya untuk saving atau menabung untuk keperluan mendadak ataupun untuk masa depan anak-anak mereka.

Walaupun fungsi BUMDes Citra Abadi belum banyak kontribusinya pada pendapatan masyarakat, tetapi ada beberapa unit usaha yang prospek kerjanya dapat terasa manfaatnya dan dapat meningkatkan pendapatan masyarakat, yaitu unit usaha pasar Kampung/Desa. Unit usaha pasar Kampung/Desa ini (Usaha Perantara) memberi pengaruh pada tingkat pendapatan masyarakatat karena unit usaha ini memiliki penghasilan yang bisa dikatakan cukup besar dalam proses pelaksanaan dengan pendapatan yang di perolehnya yaitu pendapatan hasil dari unit usaha pasar Kampung/Desa didapat dari retribusi parkir dan juga salar pedagang(penyewaan tempat). Penerimaan dari unit usaha pasar kampung dari tahun 2018 sampai tahun 2020 sekitar Rp. 200.000 juta, dengan lapak atau tempat penyewaan tempat sebanyak 6 blok dengan jumlah petak 268 petak. Penerimaan dari pasar desa didapatkan dari salar atau uang keamanan, parkir dan penyewaan lapak setiap tahunnya. Sewa tempat yang berlaku dipasar desa tersebut yakni Rp. 1.750 .000 untuk pedagang yang menggunakan lapak sewa tetap dipasar tersebut, sedangakan untuk lapak yang tidak permanen setiap tahunnya dikenakan biaya sewa Rp. 125.000. Bisa dilihat sumber penerimaan dari unit-unit usaha BUMDes Citra Abadi dikatakan cukup besar. Dalam menjalankan unit usaha pasar kampung/desa ini juga melibatkan 
masyarakat didalamnya sehingga tentunya dari banyaknya penghasilan yang didapatkan unit usaha ini pastinya berpengaruh juga pada tingkat pendapatan pedagang juga masyarakat yang memiliki tokoh disekitar pasar. Sedangkan unit usaha peternakan juga memiliki peluang untuk dikembangkan sehingga dapat membantu perekonomian masyarakat Desa Bahomotefe pada unit usaha.

\section{PENUTUP}

Berdasarkan hasil analisis Fungsi BUMDes Citra Abadi dalam upaya meningkatkan kondisi kehidupan sosial ekonomi masyarakat dapat dikemukakan beberapa hal sebagai kesimpulan dalam penelitian ini, yaitu:

1. Fungsi BUMDes dalam Meningkatkan Peranan Masyarakat Desa sudah memberikan pengaruh pada upaya peningkatan kondisi sosial yaitu pada interaksi sosial yang mana dapat dilihat dalam proses pembentukan sampai pada tingkat pelaksanaan BUMDes Bahomotefe sudah terbangun interaksi sosial seperti hubungan yang menyangkut perseorangan, menyangkut antara kelompok-kelompok. Sedangkan pada kondisi sosial pendidikan dan kesehatan belum memberikan fungsi yang khusus.

2. Fungsi BUMDes dalam Menumbuhkembangan Kegiatan Ekonomi Masyarakat Desa sudah memberikan pengaruh pada upaya peningkatan kondisi ekonomi yaitu pada pemenuhan kebutuhan rumah tangga melalui Unit Usaha pasar Kampung/Desa. Disini BUMDes Citra Abadi dalam Unit Usaha pasar desa membantu masyarakat, dimana masyarakat dapat memenuhi kebutuhan sehari-hari mereka dengan berjualan dan berbelanja dipasar desa yang telah ada dengan harga yang relatif terjangkau sehingga tidak perlu jauh jauh harus kepasar yang berada di Kecamatan/Kota untuk memenuhi kebutuhan sehari-harinya.

3. Fungsi BUMDes dalam Meningkatkan Pendapatan Masyarakat dan Pendapatan Asli Desa (PADes) Desa sudah memberikan pengaruh pada upaya peningkatan kondisi ekonomi yaitu pada pendapatan melalui Unit Usaha pasar Kampung/Desa dan Unit Usaha Peternakan yang di jalankan oleh BUMDes. Unit usaha pasar Kampung/Desa ini (Usaha Perantara) memberi pengaruh pada tingkat pendapatan masyarakatat karena unit usaha ini memiliki penghasilan yang bisa dikatakan cukup besar dalam 
proses pelaksanaannya. Sedangkan unit usaha peternakan juga memiliki peluang untuk dikembangkan sehingga dapat membantu perekonomian masyarakat Desa Bahomotefe pada unit usaha.

\section{DAFTAR PUSTAKA}

Agus, Adari. 2017. Analisis Hukum Pembentukkan BUMDes dalam Upaya Meningkatkan Pendapatan Asli Desa di Kecamatan Babalan Kabupaten Langkat. Dialogia Iuridica. Vol.9, No.1: 13-28.

Asaka, D. S., \& Olabode Awarun. (2020). Understanding Mechanistic Explanation as A Strategy of Analytical Sociology. Indonesian Journal of Social and Environmental Issues (IJSEI), 1(3), 191-197.

Harita, Juhaepa, Upe, A. (2020). Pemberdayaan Masyarakat Suku Bajo Melalui Badan Usaha Milik Desa Bunga Karang di Desa Santiri Kecamatan Tiworo Utara Kabupaten Muna Barat. Jurnal Kesejahteraan dan Pelayanan Sosial, 1 (2).

Hidayat. 2006. Sosiologi Pedesaan: Mencari Suatu Strategi Pembangunan Masyarakat Berparadigma Ganda. Jakarta: Adioffiset

Jauhar, Arifin,. Suriani, Eddy. 2018. Analisis Prinsip Bumdes di Desa Takulat Kecamatan Kelua Kabupaten Tabalong. Jurnal Administrasi Publik dan Administrasi Bisnis. Vol.1, No.2: 553-565.

Kencana

Kurniawan, Ade Eka. 2015. Peranan Badan Usaha Milik Desa (BUMDes) Dalam

Peningkatan Pendapatan Asli Desa. Jurnal Program Studi Ilmu Pemerintahan. Vol. 1, Tahun 2015.

Maryunani. 2008. Pembangunan BUMDES dan Pemberdayaan Pemerintah Desa. Bandung: CV Pustaka Setia.

Permendesa PPTT no.4 Tahun 2015 tentang Badan Usaha Milik Desa.

Pradnyani, Ni Luh Putu S P. 2019. Peran BUMDes Dalam Meningkatkan Kesejahteraan Masyarakat. Jurnal Riset Akutansi. Vol. 9, No. 2, 39-47.

Sugiyono. 2018. Metode Penelitian Kuntitatif Kualitatif dan RED. Bandung: Alfabeta. 